\title{
EKSEGESIS SYAIR LAGU WAJIB NASIONAL BERDASARKAN KAJIAN HERMENEUTIK GUNA MEMAHAMI MAKNA DAN PESAN KEPAHLAWANAN UNTUK PENANAMAN KARAKTER PADA ANAK
}

\author{
Gatut Setiadi \\ Institut Agama Islam Sunan Kalijogo Malang
}

\begin{abstract}
Abstrak
Eksegesis merupakan sebuah tindakan untuk menafsirkan serta memberikan berbagai pejelasan dari suatu teks agar dapat mengungkapkan makna yang terkandung dalam teks tersebut. Pemahaman makna teks sangat penting karena dengan memahami makna tersebut maka maksud atau pesan dari pembicara atau penulis dapat dipahami dengan baik. Seperti halnya makna tersirat dalam syair lagu perjuangan yang menyampaikan pesan-pesan kepahlawanan bagi bangsa Indonesia.

Lagu wajib nasional merupakan bagian dari lagu perjuangan, yakni lagu fenomenal yang menjadi sejarah perjuangan bangsa Indonesia dalam mencapai kemerdekaan dan menjadi kepribadian serta ciri khas bangsa Indonesia. Untuk memahami pesan di dalam syair lagu wajib nasional diperlukan analisis dan interpretasi pada syair lagu tersebut, sehingga sangat relevan untuk ditinjau dan dianalisa dari perspektif hermeneutik yakni menafsirkan suatu kata, kalimat, paragraf atau keseluruhan teks untuk menemukan makna dalam teks tersebut.

Penelitian ini dilakukan dengan melakukan analisis dan interpretasi terhadap ketujuh teks lagu wajib nasional yang diciptakan mulai tahun 1924 sampai 1949. Pendekatan yang digunakan dalam penelitian ini ada dua, yaitu pendekatan struktural dan pendekatan historis. Pengumpulan data yang dilakukan oleh peneliti menggunakan teknik pustaka atau studi kepustakaan. Hasil penelitian menunjukkan bahwa peneliti menemukan berbagai macam pesan kepahlawanan di dalam ketujuh teks lagu wajib nasional tersebut, antara lain (1) Nasionalisme, yang meliputi sifat kebanggaan terhadap Negara, cinta tanah air, mengutamakan rasa persatuan dan kesatuan. (2) Patriotisme meliputi sifat, rela berkorban, berani berjuang, pantang menyerah, berjiwa pembaharu. Pesan kepahlawanan ini jika dipahami dengan baik sejak tingkat dasar akan menjadi landasan pembentukan karakter anak bangsa yang memiliki nasionalisme dan patriotisme terhadap bangsanya, yakni bangsa Indonesia.
\end{abstract}

Kata Kunci: eksegesis, hermeneutik, kepahlawanan, syair lagu wajib nasional, karakter

PENDAHULUAN

Lagu selain sebagai media hiburan juga merupakan sebuah sarana yang digunakan manusia untuk menyampaikan aspirasi, imajinasi, pesan, guna mempengaruhi pendengar, maupun kritikan terhadap keadaan lingkungan sekitarnya. Seperti pada masa sebelum kemerdekaan sampai masa revolusi Indonesia yakni 
antara tahun 1924 sampai tahun 1949 dimana pada tahun tersebut bangsa Indonesia berusaha berjuang merebut dan mempertahankan kemerdekaan, bukan hanya melalui senjata tetapi juga melalui sarana lagu. Para komponis-komponis Indonesia berusaha menciptakan lagu berdasarkan keadaan pada masa itu sebagai wujud dari perjuangan mereka, sehingga lahirlah lagu-lagu perjuangan seperti yang dikenal saat ini.

Dalam pengertian yang luas lagu-lagu perjuangan disebut sebagai lagu wajib nasional yang diajarkan mulai pada tingkat pendidikan dasar hingga perguruan tinggi dan wajib diketahui oleh seluruh masyarakat Indonesia. Ditegaskan pula menurut peraturan pemerintah berdasarkan Instruksi Menteri Muda Pendidikan Pengajaran dan Kebudayaan No. 1 tanggal 17 Agustus 1959 yang diterbitkan oleh Balai Pustaka tahun 1963, telah ditetapkan 7 buah lagu perjuangan sebagai lagu wajib nasional yaitu.

\section{1) Lagu kebangsaan "Indonesia Raya" ciptaan Wage Rudolf Supratman.}

2) Lagu "Bagimu Negeri" ciptaan Kusbini.

3) Lagu "Maju Tak Gentar" ciptaan Cornel Simanjuntak.

4) Lagu "Halo-halo Bandung" ciptaan Ismail Marzuki.

5) Lagu "Rayuan Pulau Kelapa" ciptaan Ismail Marzuki.

6) Lagu "Berkibarlah Benderaku" ciptaan Ibu Soed (Saridjah Niung Bintang Soedibjo).

7) Lagu "Satu Nusa Satu Bangsa" ciptaan Liberty Manik.

Ketujuh lagu wajib nasional dipilih karena ada beberapa alasan, alasan- alasan diplihnya ketujuh lagu wajib nasional tersebut dijelaskan sebagai berikut ini:

1) Kurang dikenalnya lagu wajib nasional oleh bangsanya sendiri.

Banyaknya lagu perjuangan di Indonesia membuktikan betapa lamanya perjuangan yang telah dilakukan oleh rakyat Indonesia untuk mendapatkan kemerdekaan. Oleh karena itu seharusnya lagu-lagu ini dikenal dan dipahami oleh semua bangsa indonesia khususnya lagu wajib nasional yang wajib diajarkan di sekolah mulai dari tingkat dasar sampai perguruan tinggi. Lagu-lagu tersebut merupakan lagu yang monumental dan mempunyai nilai sejarah yang sangat luar biasa serta memiliki makna, pesan juga fungsi yang sangat besar bagi perjuangan bangsa Indonesia. Tetapi seiring dengan perkembangan zaman lama kelamaan lagu perjuangan khususnya lagu wajib nasional hanya dikenal oleh bangsa Indonesia sebagai lagu seremonial saja, maksudnya yaitu hanya sebuah lagu yang dinyanyikan sebagai sarana pelengkap pada saat acara-acara resmi seperti upacara bendera, acara peringatan hari kemerdekaan, rapat kenegaraan dan lain-lain, yang mengakibatkan lagulagu wajib nasional kurang dikenal oleh bangsanya sendiri. Pada umumnya lagu wajib nasional hanya dipahami sebatas hafalan baik melodi maupun syairnya saja, yang kurang dipahami adalah latar belakang sejarah dan pengarangnya, serta tujuan lagu-lagu itu diciptakan, dan yang lebih penting lagi makna serta pesan yang ingin disampaikan oleh pengarang melalui lirik lagu tersebut. 
Jika hal seperti ini dibiarkan terus menerus, maka lagu wajib nasional hanya akan dianggap sebatas tembang kenangan belaka, serta akan hilang pengaruhnya bagi bangsa Indonesia, hingga pada suatu saat nanti mungkin akan punah digantikan dengan lagulagu terbaru yang ada pada saat ini. Memang lagu wajib nasional kurang sesuai dengan trend model lagu yang sekarang ini, tetapi di dalam lagu wajib nasional itu jika dipahami dengan benar maka terdapat pesan-pesan heroik yang sangat sesuai untuk digunakan bagi bangsa Indonesia sepanjang masa.

\section{2) Nilai sejarahnya}

Jika dibandingkan dengan lagu-lagu perjuangan pada masa sekarang, lagu wajib nasional memiliki unsur sejarah yang lebih tinggi nilainya, karena lagu wajib nasional merupakan lagu-lagu yang diciptakan pada tahun 1924 sampai 1949 dan dilatar belakangi oleh perjuangan bangsa Indonesia pada masa itu dalam merebut dan mempertahankan kemerdekaan, jadi secara otomatis ada nilai sejarah yang terkandung di dalamnya, yang semuanya itu tidak terdapat dalam lagu perjuangan pada masa sekarang. Maka unsur sejarah dalam lagu inilah yang harus dapat dipertahankan sampai kapanpun, karena lagu wajib nasional adalah bagian dari sejarah panjang perjuangan bangsa Indonesia dalam meraih kemerdekaannya.

\section{3) Fungsinya}

Berdasarkan fungsinya, lagu wajib nasional tersebut memiliki fungsi yang sangat penting baik di masa lalu maupun di masa sekarang. Fungsi dari lagu perjuangan dibedakan menjadi dua, pertama fungsi primer, yaitu sebagai sarana dalam upacara dan yang kedua fungsi sekunder, yaitu sebagai sarana untuk meningkatkan semangat dan agitasi masyarakat indonesia. Dari ketujuh lagu tersebut yang memiliki fungsi primer adalah lagu kebangsaan "Indonesia Raya" ciptaan W.R. Supratman, karena lagu tersebut memiliki makna sebagai sarana upacara, yang sampai sekarangpun wajib dinyanyikan pada saat upacara bendera, sedangkan yang menjadi fungsi sekunder yaitu Lagu "Bagimu Negeri" ciptaan Kusbini, Lagu "Maju Tak Gentar" ciptaan Cornel Simanjuntak, Lagu "Halo-halo Bandung" ciptaan Ismail Marzuki, Lagu "Rayuan Pulau Kelapa" ciptaan Ismail Marzuki, Lagu "Berkibarlah Benderaku" ciptaan Saridjah Niung Bintang Soedibjo, Lagu "Satu Nusa Satu Bangsa" ciptaan Liberty Manik, karena lagu tersebut diciptakan untuk meningkatkan semangat juang bangsa Indonesia dalam merebut dan mempertahankan kemerdekaan, dan pada masa sekarang lagu tersebut tetap dikumandangkan dalam acara H.U.T R.I untuk mengingatkan semangat juang pada masa lalu.

\section{4) Nilai pendidikannya}

Lagu wajib nasional merupakan lagulagu perjuangan yang wajib diajarkan di tiap-tiap sekolah mulai dari tingkat dasar sampai perguruan tinggi, sesuai dengan peraturan pemerintah berdasarkan Instruksi Menteri Muda Pendidikan Pengajaran dan Kebudayaan No. 1 tanggal 17 Agustus 1959 yang diterbitkan oleh Balai Pustaka tahun 1963. Jadi lagu wajib nasional ini merupakan lagu-lagu yang menjadi bagian dari pembelajaran disekolah dan harus diajarkan pada anak didik. Karena lagu wajib nasional ini jika diajarkan dan diperkenalkan 
kepada anak didik dengan baik dan benar bukan hanya dari lirik lagu dan cara menyanyikannya, tetapi juga dari sejarah, latar belakang pengarang, makna serta pesan yang terdapat di dalam lagu tersebut maka akan dapat menciptakan dan mengembangkan karakter anak didik yang memiliki sifat nasionalisme dan patriotisme sesuai dengan program pendidikan budaya dan karakter bangsa yang dicanangkan oleh pemerintah sekarang ini.

\section{5) Para pengarang komponisnya}

Para pengarang atau komponis lagu wajib nasional ini menciptakan lagu tersebut bukan didasarkan untuk mendapatkan materi, penghargaan atau nama baik, tetapi mereka melakukannya hanya karena rasa nasionalisme dan patriotisme terhadap bangsa Indonesia tanpa mengharapkan imbalan dalam bentuk apapun. Sikap dan tingkah laku para pengarang atau komponis lagu wajib nasional inilah yang dapat menjadi suri tauladan bagi anak didik di sekolahsekolah, dan juga bagi masyarakat pada umumnya.

Manusia menciptakan lagu sesuai peranan lagu sebagai alat untuk berimajinasi, menyampaikan inspirasi, keinginan, dan mengekspresikan diri, maka akan ada pesan-pesan yang terkandung dalam tiap-tiap bait lagu tersebut yang ingin disampaikan oleh si pengarang. Pesan yang disampaikan oleh seorang pencipta lagu bersumber pada pola pikir serta kerangka acuan (frame of reference) dan pengalaman (field of experience) sebagai hasil interaksinya dengan lingkungan sosial disekitarnya. Konsep pesan dalam sebuah lagu biasanya bermacammacam. Karena di setiap penciptaan lagu, seorang pencipta berusaha untuk menyampaikan suatu pesan untuk khalayak dan hak tersebut adalah sebuah realitas atau fenomena yang dirasakan oleh pencipta lagu, misalnya rasa cinta, kecewa, benci, kritik sosial yang ditujukan kepada pemerintah, isu-isu sosial di masyarakat, bahkan untuk menumbuhkan semangat nasionalisme dan patriotisme terhadap bangsa dan negara.

Untuk mengetahui dan memahami pesan yang terkandung dalam lirik lagu wajib nasional perlu diadakannya interpretasi terhadap lirik lagu tersebut, sebab sebuah lirik lagu terdiri dari beberapa teks, setiap teks yang ditulis memiliki banyak variabel, seperti tujuan penulisan, sejarah, suasana politis, ekonomis, psikologis, budaya dan lain sebagainya, sehingga ketika wacana yang bersifat spontan dan dialogis dituangkan dalam sebuah teks, maka sangat potensial akan melahirkan salah paham di kalangan pembacanya sesuai dengan pendapat dari (Hidayat, 1996: 17). Demikian pula halnya dengan lirik lagu wajib nasional yang tidak lepas dari variabel-variabel tersebut, maka kajian hermeneutika sangat penting sekali peranannya dalam hal ini. Secara etimologis menurut Palmer (2005: 14) kata hermeneutika berasal dari bahasa Yunani "hermeneuein" yang berarti menafsirkan. Kata bendanya "hermeneia" yang berarti interpretasi, penafsiran, ungkapan, pemberitahuan dan terjemah. Secara umum hermeneutik merupakan sebuah cabang ilmu yang menjelaskan suatu teks, wacana, syair atau lirik dan lainlain dengan cara menafsirkan susunan kata, kalimat dan juga sejarahnya. 


\section{TINJAUAN PUSTAKA}

Tinjauan pustaka adalah sebuah tinjauan komprehensif, yakni menjelaskan tentang topik penelitian, juga teori para ahli yang digunakan berhubungan dengan konsep-konsep penting sesuai dengan penelitian yang akan dibahas secara keseluruhan. Castetter dan Heisler (1984, p.38) menjelaskan bahwa tinjauan pustaka mempunyai enam kegunaan yaitu, 1) mengkaji sejarah permasalahan, 2) membantu pemilihan prosedur penelitian, 3) mendalami landasan teori yang berkaitan dengan permasalahan, 4) mengkaji kelebihan dan kekurangan hasil penelitian terdahulu, 5) menghindari duplikasi penelitian, dan 6) menunjang perumusan permasalahan. Jadi penjelasan tentang tinjauan pustaka yang akan diuraikan meliputi:

1) Eksegesis

2) lagu perjuangan,

3) pengertian kepahlawanan,

4) hermeneutika.

5) karakter

\section{Eksegesis}

Berdasarkan wikipedia, eksegesis merupakan sebuah tindakan yang memiliki tujuan "membawa keluar atau mengeluarkan". Sedangkan berdasarkan $\mathrm{KBBI}$ offline $\mathrm{V} . \quad 1.5$ mengartikan eksegesis sebagai suatu penjelasan atau penafsiran pada suatu teks. Jadi secara umum eksegesis merupakan sebuah tindakan untuk menafsirkan dan menjelaskan secara terperinci tentang suatu hal, khususnya berkaitan dengan teks atau syair, sebab kalimat dan tata bahasa dalam suatu teks atau syair terkadang membutuhkan penafsiran yang mendalam untuk memahami makna dan pesan yang terdapat di dalamnya.
Dengan memahami makna serta pesan maka maksud dan tujuan penulis dapat tersampaikan dan dipahami oleh penerima pesan atau pembaca. Beberapa teks yang membutuhkan suatu penafsiran yang mendalam untuk memahami maknanya selain kitab suci yakni syair dalam sebuah lagu, khususnya lagu-lagu perjuangan

\section{Lagu Perjuangan}

Lagu merupakan sebuah media hiburan yang banyak dikenal oleh manusia, selain itu lagu juga digunakan sebagai sarana untuk menyampaikan gagasan, kritikan terhadap keadaan lingkungan sekitar, mempengaruhi pendengar dan lain sebagainya. Lagu merupakan perwujudan dari puisi yang digabungkan dengan sarana musik. Dalam Kamus Besar Bahasa Indonesia offline lagu diartikan sebagai ragam suara yang berirama. Sedangkan menurut Pono Banoe (2003: p.233), lagu dipahami sebagai nyanyian atau melodi pokok. Dari dua pengertian tersebut dapat disimpulkan bahwa lagu adalah beragam suara yang memiliki susunan bunyi sehingga menciptakan berbagai nada (tinggi rendahnya bunyi) secara teratur. Salah satu jenis lagu yang banyak dikenal oleh bangsa Indonesia adalah lagu perjuangan.

Lagu perjuangan Indonesia disebut sebagai musik fungsional yaitu musik yang diciptakan untuk tujuan nasional. Unsur teknis bernyanyi dalam lagu perjuangan secara estetis tidak begitu penting, karena yang diutamakan adalah makna serta isi teks lagu yang bersifat upacara atau bersifat agitasi yang disampaikan kepada masyarakat pendukungnya, oleh karena itu dalam penciptaanya lagu perjuangan dibagi menjadi tiga tahap. Pertama, melodi 
diciptakan dengan pola sederhana agar mudah dinyanyikan oleh berbagai lapisan masyarakat Indonesia, kedua, teks syair atau lirik lagu menggunakan bahasa Indonesia agar mudah dipahami oleh seluruh masyarakat Indonesia yang memiliki beragam bahasa daerah, dan yang ketiga, peranan munculnya lagu-lagu perjuangan Indonesia adalah akibat adanya tekanan dan penindasan dari kaum penjajah pada masa perjuangan dan perang kemerdekaan di Indonesia. Sehingga lagu perjuangan menjadi sarana untuk membangkitkan semangat juang rakyat Indonesia.

Lagu-lagu perjuangan berdasarkan waktu penciptaannya dapat diklasifikasikan menjadi 3 periode. Pertama, lagu-lagu perjuangan yang di ciptakan pada masa prakemerdekaan tahun 1924-1945 contohnya lagu "Indonesia Raya" karya W.R.Soepratman, Kedua, lagu-lagu yang diciptakan pada masa revolusi Indonesia yakni mulai tahun 19451949, contohnya lagu "Maju Tak Gentar" karya Cornel Simanjuntak, dan ketiga, lagu-lagu perjuangan yang diciptakan pada masa pasca kemerdekaan yakni tahun 1950 ke atas, contohnya lagu "Andika Bhayangkari" karya Amir Pasaribu.

Ditegaskan pula menurut peraturan pemerintah berdasarkan Instruksi Menteri Muda Pendidikan Pengajaran dan Kebudayaan No. 1 tanggal 17 Agustus 1959 yang diterbitkan oleh Balai Pustaka tahun 1963, telah ditetapkan tujuh buah lagu perjuangan sebagai lagu wajib yaitu, (1) Lagu kebangsaan "Indonesia Raya" ciptaan Wage Rudolf Supratman. (2) Lagu "Bagimu Negeri" ciptaan Kusbini. (3) Lagu "Maju Tak Gentar" ciptaan Cornel
Simanjuntak. (4) Lagu "Halo-halo Bandung" ciptaan Ismail Marzuki. (5) Lagu "Rayuan Pulau Kelapa" ciptaan Ismail Marzuki. (6) Lagu "Berkibarlah Benderaku" ciptaan Bintang Sudibyo. (7) Lagu "Satu Nusa Satu Bangsa" ciptaan Liberty Manik.

\section{Pengertian Kepahlawanan}

Dalam Kamus Besar Bahasa Indonesia (KBBI) offline, kepahlawanan diartikan sebagai bersifat kepahlawanan. Sifat kepahlawanan yang disampaikan dalam lagu wajib nasional ditujukan untuk seluruh rakyat Indonesia, agar rakyat dapat memberikan perilaku seorang pahlawan bagi Negara Indonesia. Sifat kepahlawanan terhadap Negara adalah nasionalisme dan patriotisme. Blank (2003) \& Schmidt (2003) melalui studi mereka berpendapat bahwa nasionalisme tidak sama dengan patriotisme. Nasionalisme lebih bernuansa dominasi, superioritas atas kelompok bangsa lain. Tingkat nasionalisme suatu kelompok atau bangsa, ditekankan pada adanya perasaan "lebih" atas bangsa lain. Dibandingkan dengan nasionalisme, patriotisme lebih berbicara akan cinta dan loyalitas.

Nasionalisme adalah suatu paham yang berpendapat bahwa kesetiaan tertinggi individu harus diserahkan kepada negara kebangsaan (Kohn,1984: p.11). Secara etimologi, nasionalisme berasal dari kata "nasional" dan "isme" yaitu paham kebangsaan yang mengandung makna kesadaran dan semangat cinta tanah air, memiliki kebanggaan sebagai bangsa, atau memelihara kehormatan bangsa, memiliki rasa solidaritas terhadap musibah dan kekurangberuntungan saudara 
setanah air, sebangsa dan senegara. Dalam Ensiklopedi Indonesia, nasionalisme adalah sikap politik dan sosial dari sekelompok bangsa yang mempunyai kesamaan kebudayaan, bahasa dan wilayah serta kesamaan cita-cita dan tujuan dengan meletakkan kesetiaan yang mendalam terhadap kelompok bangsanya. Nasionalisme diartikan juga sebagai paham yang menciptakan dan mempertahankan kedaulatan negara (nation) dengan mewujudkan suatu konsep identitas bersama untuk sekelompok manusia.

Berdasarkan dari pengertian tersebut maka dapat disimpulkan bahwa nasionalisme adalah paham yang meletakkan kesetiaan tertinggi individu yang harus diberikan kepada negara dan bangsanya, dengan maksud bahwa individu sebagai warga negara memiliki suatu sikap atau perbuatan untuk mencurahkan segala tenaga dan pikirannya demi kemajuan, kehormatan dan tegaknya kedaulatan negara dan bangsa. Rasa Nasionalisme ini yang kemudian mendorong seseorang untuk memiliki perasaan rela berkorban sebagai wujud rasa cinta terhadap tanah air. Ada 2 macam nasionalisme yaitu,

1) nasionalisme dalam arti sempit yakni paham kebangsaan yang berlebihan dengan memandang bangsa sendiri lebih tinggi (unggul) dari bangsa lain. Paham ini sering disebut dengan istilah "Chauvinisme". Chauvinisme pernah dianut di Italia (masa Bennito Mussolini), Jepang (masa Tenno Haika) dan Jerman (masa Adolf Hitler).

2) nasionalisme dalam arti luas yakni paham kebangsaan yang meletakkan kesetiaan tertinggi individu terhadap bangsa dan tanah airnya dengan memandang bangsanya itu merupakan bagian dari bangsa lain di dunia. Nasionalisme arti luas mengandung prinsip-prinsip, kebersamaan, persatuan dan kesatuan, serta demokrasi (demokratis).

Patriotisme berdasarkan KBBI offline berasal dari kata "Patriot" yang diartikan pecinta atau pembela tanah air dan "isme" yakni sistim kepercayaan berdasarkan politik sosial dan ekonomi' Jadi patriotisme adalah sifat yang bersumber dari perasaan cinta tanah air (semangat kebangsaan atau nasionalisme) dan berhubungan dengan lingkungan sekitar (Negara), dalam bahasa Inggris Patriotism diartikan yang berarti sikap gagah berani, pantang menyerah dan rela berkorban demi bangsa dan negara. Patriotisme adalah sikap yang bersumber dari perasaan cinta tanah air (semangat kebangsaan atau nasionalisme), sehingga menimbulkan kerelaan berkorban untuk bangsa dan negaranya. Ada 2 bentuk Patriotisme.

1) Patriotisme Buta (Blind Patriotism) yakni keterikatan kepada bangsa dan Negara tanpa mengenal toleran terhadap kritik, seperti dalam ungkapan "right or wrong is my country" (benar atau salah, apapun yang dilakukan bangsa harus didukung sepenuhnya).

2) Patriotisme Konstruktif (Constructive Patriotisme) keterikatan kepada bangsa dan negara dengan tetap menjunjung tinggi toleransi terhadap kritik, sehingga dapat membawa 
perubahan positif bagi kesejahteraan bersama.

Perwujudan sikap patriotisme dapat dilaksanakan pada, 1) Masa Darurat (Perang), sikap patriotisme pada masa darurat (perang) dapat diwujudkan dengan cara mengangkat senjata, ikut berperang secara fisik melawan penjajah, menjadi petugas logistik, menolong yang terluka, dan lain sebagainya. 2) Masa Damai (Pasca kemerdekaan), Sikap patriotisme pada masa damai dapat diwujudkan dengan cara menegakkan hukum dan kebenaran, memajukan pendidikan, memberantas kebodohan dan kemiskinan, meningkatkan kemampuan diri secara optimal, memelihara persaudaraan dan persatuan, dan lain-lain. Patriotisme merupakan sikap sudi mengorbankan segala-galanya untuk kejayaan tanah air, bangsa, dan Negara, sedangkan ciri-cirinya sendiri adalah, cinta tanah air, rela berkorban untuk kepentingan bangsa dan Negara, mengutamakan persatuan, kesatuan, serta keselamatan bangsa dan negara diatas kepentingan pribadi dan golongan, Berjiwa pembaharu, Tidak kenal menyerah. Sikap-sikap seperti inilah yang diharapkan dimiliki oleh seluruh masyarakat Indonesia.

\section{Hermeneutika}

Pada dasarnya hermeneutika berusaha memahami apa yang dikatakan dengan kembali pada motivasinya atau kepada konteksnya, diperlukan konsep kuno yang bernama "kata batin" (inner word). Sebagai sebuah metode penafsiran, hermeneutika memperhatikan tiga hal sebagai komponen pokok dalam kegiatan penafsiran yakni teks, konteks dan kontekstualisasi. Dengan demikian setidaknya terdapat tiga pemahaman mengenai hermeneutika yakni.

1) Sebagai teknik praksis (bidang kehidupan dan kegiatan praktis manusia) pemahaman atau penafsiran, dekat dengan eksegesis, yakni kegiatan memberi pemahaman tentang sesuatu atau kegiatan untuk mengungkapkan makna tentang sesuatu agar dapat dipahami.

2) Sebagai sebuah metode penafsiran, tentang the conditions of possibility sebuah penafsiran. Hal-hal apa yang dibutuhkan atau langkah-langkah bagaimana harus dilakukan untuk menghindari pemahaman yang keliru terhadap teks.

3) Sebagai penafsiran fisafat.

Karena objek utama hermeneutika adalah teks dan teks adalah hasil atau produk praksis berbahasa, maka antara hermeneutika dengan bahasa akan terjalin hubungan sangat dekat.

Hermeneutika adalah studi pemahaman, khususnya tugas pemahaman teks (Palmer, 2005: p.14). Secara etimologis kata hermeneutik berasal dari bahasa Yunani "hermeneuein" yang berarti menafsirkan. Kata bendanya "hermeneia" yang berarti interpretasi, penafsiran, ungkapan, pemberitahuan dan terjemah (Palmer, 2005: 14), sedangkan Lorens Bagus (2000: 283) berpendapat hermeneutik berarti ilmu atau teori tentang penafsiran yang bertujuan menjelaskan teks mulai dari ciri-cirinya, baik obyektif (arti gramatikal kata-kata dan variasi-variasi historisnya), maupun secara subyektif (unsur-unsur yang mempengaruhinya). Dari terminologi ini, bisa diartikan hermeneutik memiliki kaitan dengan 
penafsiran atau interpretasi. Secara sederhana, dapat dikatakan fokus hermeneutik adalah masalah pemahaman, penafsiran dan penerjemahan atas sebuah teks (Hidayat, 1996: p.14). Secara umum hermeneutik diartikan sebagai proses mengubah ketidaktahuan menjadi mengerti (Sumaryono, 1999: 23-24). Dan pengertian yang lain dari hermeneutika yakni metode atau cara untuk menafsirkan simbol berupa teks untuk dicari arti dan maknanya, metode ini mensyaratkan adanya kemampuan untuk menafsirkan masa lampau yang tidak dialami, kemudia di bawa ke masa depan. Dapat disimpulkan bahwa hermeneutika merupakan sebuah cabang ilmu yang menjelaskan suatu teks, wacana, syair, lirik dan lain-lain dengan cara menafsirkannya dan menginterpretasikan susunan kata, kalimat dan juga sejarahnya.

Bagan Hermeneutika Romantisme Friedrich Ernst Daniel Schleiermacher

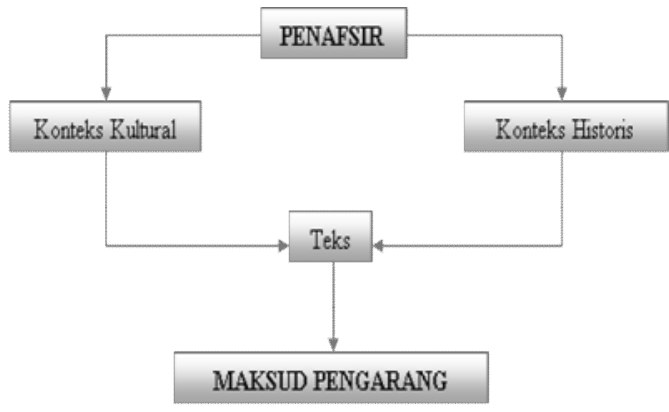

\section{Pendidikan Berkarakter}

Pengertian karakter menurut Pusat Bahasa Depdiknas adalah "bawaan, hati, jiwa, kepribadian, budi pekerti, perilaku, personalitas, sifat, tabiat, temperamen, watak". Adapun pengertian yang lain yakni berkarakter adalah berkepribadian, berperilaku, bersifat, bertabiat, dan berwatak". Menurut Tadkiroatun Musfiroh (UNY,
2008) karakter mengacu kepada serangkaian sikap (attitudes), perilaku (behaviors), motivasi (motivations), dan keterampilan (skills). Karakter berasal dari bahasa Yunani yang berarti "to mark" atau menandai dan memfokuskan bagaimana mengaplikasikan nilai kebaikan dalam bentuk tindakan atau tingkah laku, sehingga orang yang tidak jujur, kejam, rakus dan perilaku jelek lainnya dikatakan orang berkarakter jelek. Sebaliknya, orang yang perilakunya sesuai dengan kaidah moral disebut dengan berkarakter mulia. Lebih lanjut dijelaskan bahwa pendidikan karakter adalah segala sesuatu yang dilakukan guru, yang mampu mempengaruhi karakter peserta didik. Guru membantu membentuk watak peserta didik. Hal ini mencakup keteladanan bagaimana perilaku guru, cara guru berbicara atau menyampaikan materi, bagaimana guru bertoleransi, dan berbagai hal terkait lainnya. Menurut T. Ramli (2003), pendidikan karakter memiliki esensi dan makna yang sama dengan pendidikan moral dan pendidikan akhlak. Tujuannya adalah membentuk pribadi anak, supaya menjadi manusia yang baik, warga masyarakat, dan warga negara yang baik. Adapun kriteria manusia, warga masyarakat, dan warga negara yang baik bagi suatu masyarakat atau bangsa, secara umum adalah nilai-nilai sosial tertentu, yang banyak dipengaruhi oleh budaya masyarakat dan bangsanya.

Oleh karena itu, hakikat dari pendidikan karakter dalam konteks pendidikan di Indonesia adalah pedidikan nilai sifat dan sikap, yakni pendidikan nilai-nilai luhur yang bersumber dari budaya bangsa 
Indonesia sendiri, dalam rangka membina kepribadian generasi muda.

Dari beberapa pengertian tersebut dapat dipahami bahwa pendidikan karakter adalah pendidikan budi pekerti plus, yaitu yang melibatkan aspek pengetahuan (cognitive), perasaan (feeling), dan tindakan (action).Tanpa ketiga aspek ini, maka pendidikan karakter tidak akan efektif, karena pendidikan karakter merupakan upaya-upaya yang dirancang dan dilaksanakan secara sistematis untuk membantu peserta didik memahami nilai-nilai perilaku manusia yang berhubungan dengan Tuhan Yang Maha Esa, diri sendiri, sesama manusia, lingkungan, dan kebangsaan yang terwujud dalam pikiran, sikap, perasaan, perkataan, dan perbuatan berdasarkan normanorma agama, hukum, tata krama, budaya, dan adat istiadat. Pendidikan karakter yang ditanamkan sejak dini akan berdampak positif pada tahuntahun mendatang, dengan muncul dan lahirnya manusia Indonesia yang unggul.

Fungsi dan tujuan pendidikan tertuang dalam Undang-Undang Nomor : 20 Tahun 2003 Bab II Pasal 3 yaitu, pendidikan nasional berfungsi mengembangkan kemampuan dan membentuk watak serta peradaban bangsa yang bermartabat, bertujuan untuk berkembangnya potensi peserta didik agar menjadi manusia yang beriman dan bertaqwa kepada Tuhan Yang Maha Esa, berakhlak mulia, sehat, berilmu, sehat, kreatif, mandiri, dan menjadi warga negara yang demokratis serta bertanggung jawab. Diantara Nilai-nilai dalam Pendidikan Karakter Bangsa, ada 18 unsur nilai karakter yang diantaranya adalah,
1) religius, yaitu sikap dan perilaku yang patuh dalam melaksanakan ajaran agama yang dianutnya, toleran terhadap pelaksanaan ibadah agama lain, dan hidup rukun dengan pemeluk agama lain

2) jujur yaitu perilaku yang didasarkan pada upaya menjadikan dirinya sebagai orang yang selalu dapat dipercaya dalam perkataan, tindakan, dan pekerjaan

3) toleransi yaitu sikap dan tindakan yang menghargai perbedaan agama, suku, etnis, pendapat, sikap, dan tindakan orang lain yang berbeda dari dirinya

4) disiplin, yaitu tindakan yang menunjukkan perilaku tertib dan patuh pada berbagai ketentuan dan peraturan

5) kerja keras, yaitu perilaku yang menunjukkan upaya sungguhsungguh dalam mengatasi berbagai hambatan belajar dan tugas, serta menyelesaikan tugas dengan sebaik-baiknya

6) kreatif, yaitu berpikir dan melakukan sesuatu untuk menghasilkan cara atau hasil baru dari sesuatu yang telah dimiliki

7) mandiri, yaitu sikap dan perilaku yang tidak mudah tergantung pada orang lain dalam menyelesaikan tugas-tugas

8) demokratis, yaitu cara berfikir, bersikap, dan bertindak yang menilai sama hak dan kewajiban dirinya dan orang lain

9) rasa ingin tahu, yaitu sikap dan tindakan yang selalu berupaya untuk mengetahui lebih 
mendalam dan meluas dari sesuatu yang dipelajarinya, dilihat, dan didengar

10) semangat kebangsaan, yaitu cara berpikir, bertindak, dan berwawasan yang menempatkan kepentingan bangsa dan negara di atas kepentingan diri dan kelompoknya

11) cinta tanah air, yaitu cara berfikir, bersikap, dan berbuat yang menunjukkan kesetiaan, kepedulian, dan penghargaan yang tinggi terhadap bahasa, lingkungan fisik, sosial, budaya, ekonomi, dan politik bangsa

12) menghargai prestasi yaitu sikap dan tindakan yang mendorong dirinya untuk menghasilkan sesuatu yang berguna bagi masyarakat, dan mengakui, serta menghormati keberhasilan orang lain

13) bersahabat/komuniktif, yaitu tindakan yang memperlihatkan rasa senang berbicara, bergaul, dan bekerja sama dengan orang lain

14) cinta damai yaitu sikap, perkataan, dan tindakan yang menyebabkan orang lain merasa senang dan aman atas kehadiran dirinya

15) gemar membaca, yaitu kebiasaan menyediakan waktu untuk membaca berbagai bacaan yang memberikan kebajikan bagi dirinya

16) peduli lingkungan, yaitu sikap dan tindakan yang selalu berupaya mencegah kerusakan pada lingkungan alam di sekitarnya, dan mengembangkan upaya-upaya untuk memperbaiki kerusakan alam yang sudah terjadi

17) peduli sosial, yaitu sikap dan tindakan yang selalu ingin memberi bantuan pada orang lain dan masyarakat yang membutuhkan

18) tanggung jawab, yaitu sikap dan perilaku seseorang untuk melaksanakan tugas dan kewajibannya, yang seharusnya dia lakukan, terhadap diri sendiri, masyarakat, lingkungan (alam, sosial dan budaya), negara dan Tuhan Yang Maha Esa.

\section{METODE PENELITIAN}

Metode penelitian digunakan agar mencapai hasil yang sesuai dengan permaslahan yang menjadi kajian dalam penelitiann "Metode penelitian pada dasarnya merupakan cara ilmiah untuk mendapatkan data dengan tujuan dan keguanaan tertentu (Sugiyono, 2009: h. 2). Langkahlangkah pelaksanaan penelitian yang dimaksud meliputi serangkaian kegiatan yang dilaksanakan dalam keseluruhan pelaksanaan penelitian, mulai dari perencanaan, pengambilan data, analisis data, sampai pada penyusunan laporan penelitian.

Karena fokus penelitian ini adalah menafsirkan dan menginterpretasikan pesan heroik pada lagu wajib nasional dengan memfokuskan pada salah satu unsur intrinsiknya yaitu lirik lagu, maka dalam penelitian ini menggunakan dua pendekatan,

1) pendekatan Struktural, yaitu metode pendekatan yang mengkaji karya sastra dengan mengungkapkan makna yang ada di dalam teks. 
serta melihat dari tahun diciptakannya yakni antara tahun 1924 sampai 1949, dan unsur sejarah yang melatarbelakangi diciptakannya lagu wajib nasional tersebut maka digunakan juga,

2) pendekatan historis, yaitu dengan mempelajari dan mengenali faktafakta dan menyusun kesimpulan mengenai peristiwa-peristiwa masa lampau, menilai dan menafsirkan fakta yang diperoleh secara sistematis dan objektif untuk dapat memahami masa lampau.

Sesuai dengan objek yang menjadi kajiannya yakni lirik lagu wajib nasional, maka jenis penelitiannya adalah Penelitian studi dokumen/teks. Studi dokumen atau teks merupakan jenis penelitian yang menitikberatkan pada analisis atau interpretasi bahan tertulis berdasarkan konteksnya. Bahan bisa berupa catatan yang terpublikasikan, buku teks, surat kabar, majalah, surat-surat, film, catatan harian, naskah, artikel, dan sejenisnya. Sedangkan metode yang digunakan untuk mengintrepretasikan lirik lagu wajib nasional ini adalah deskriptif kualitatif, yaitu metode yang menggambarkan keadaan atau suatu fenomena, karena penulis bertujuan mendeskripsikan pesan heroik yang terkandung di dalam lirik lagu tersebut.

Data dan sumber data merupakan hal yang menjadi sarana penting dalam sebuah penelitian. Data yaitu keterangan yang benar dan nyata atau bahan nyata yang dapat dijadikan dasar kajian (analisis atau kesimpulan) dari berbagai informasi yang diperoleh (KBBI) offline, sedangkan sumber data adalah subyek asal data itu diperoleh. Sudaryanto (1998:28) mengemukakan bahwa sumber data ialah seseorang atau sesuatu bahan bagi objek penelitian. Jadi data yang digunakan dalam penelitian ini adalah berupa kata-kata, atau kalimat yang terdapat didalam ketujuh lirik lagu wajib nasional yang membutuhkan penjelasan lebih komprehensif dalam memahaminya, sehinggga perlu diinterpretasikan terlebih dahulu. sumber data dalam penelitian ini adalah ketujuh lirik lagu wajib nasional yaitu,

1) lagu kebangsaan "Indonesia Raya" ciptaan Wage Rudolf Supratman

2) lagu "Bagimu Negeri" ciptaan Kusbini

3) lagu "Maju Tak Gentar" ciptaan Cornel Simanjuntak

4) lagu "Halo-halo Bandung" ciptaan Ismail Marzuki

5) lagu "Rayuan Pulau Kelapa" ciptaan Ismail Marzuki

6) lagu "Berkibarlah Benderaku" ciptaan Bintang Soed (Saridjah Niung Bintang Soedibjo)

7) Lagu "Satu Nusa Satu Bangsa" ciptaan Liberty Manik

Teknik yang dilakukan peneliti dalam memperoleh dan mengumpulkan data adalah dengan menggunakan teknik pustaka atau studi kepustakaan, teknik pustaka adalah segala usaha yang dilakukan oleh peneliti untuk menghimpun informasi yang relevan dengan topik atau masalah yang akan atau sedang diteliti, dengan mengumpulkan, mencari, mempelajari dengan membaca buku-buku dan sumber-sumber tertulis yang berhubungan dengan objek penelitian. Nazir (1998: h. 112) mengungkapkan, studi kepustakaan merupakan langkah yang penting dimana setelah seorang peneliti menetapkan topik penelitian, 
langkah selanjutnya adalah melakukan kajian yang berkaitan dengan teori yang berkaitan dengan topik penelitian. Teknik pustaka adalah teknik yang menggunakan sumbersumber tertulis untuk memperoleh data (Subroto, 1992: h. 42).

Teknik analisis data yang digunakan dalam penelitian ini adalah teknik analisis deskriptif kualitatif, yakni mendeskripsikan sesuatu dengan rinci dalam bentuk kata-kata berdasarkan rumusan masalah yang telah ditentukan. Langkah-langkah yang dilakukan dalam teknik analisis deskriptif kualitataif yaitu,

1) reduksi data, yakni proses mengumpulkan data penelitian

2) penyajian data, yakni dalam hal ini adalah dengan mengidentifikasi, mengklasifikasi, menafsirkan dan menginterpretasikan data berdasarkan tujuan penelitian

3) mengambil kesimpulan lalu diverifikasi, dalam hal ini peneliti merevisi hasil analisis yang kurang sesuai, dan memaparkan hasil analisis tersebut

Data yang diperoleh perlu diketahui validitasnya, untuk mengetahui validitas data yang telah diperoleh, dikumpulkan dan dicatat dalam kegiatan penelitian, maka ditentukan cara-cara yang tepat untuk mengembangkan tingkat kebenaran data yang diperoleh. Karena jenis penelitian ini adalah studi dokumen/teks maka pengecekan validitas data yang dilakukan adalah,

1) dengan teknik peningkatan ketekunan, peneliti memusatkan diri pada tujuan penelitian untuk menemukan data yang relevan

2) pemeriksaan sejawat melalui diskusi yakni dengan mengekspos hasil sementara atau yang telah diperoleh melalui diskusi dengan dosen pembimbing, dan para ahli dibidang ilmu yang menjadi objek atau kajian di dalam penelitian

3) memakai bahan referensi lain dari berbagai media yang digunakan sebagai pembanding tingkat kebenaran data

Prosedur penelitian yang dilakukan dalam penelitian ini sebagai berikut ini.

1) Tahap Persiapan, meliputi penetapan masalah yang akan dikaji dalam penelitian, menyusun rancangan penelitian dengan topik yang telah ditetapkan, melakukan studi pustaka.

2) Tahap Perencanaan, menentukan data-data apa saja yang dibutuhkan dalam melaksanakan penelitian nanti, dan langkah-langkah yang akan dilakukan dalam penelitian.

3) Tahap Pelaksanaan, meliputi pengumpulan dan pengolahan data sesuai dengan rumusan masalah, dan menganalisa data-data yang diperoleh

4) Tahap Penyelesaian, mnyimpulkan hasil temuan data dan hasil penafsiran untuk menentukan pesan dalam syair lagu perjuangan Agar lebih memudahkan dalam menemukan hasil dalam penelitian, maka dibutuhkan instrumen penelitian. Instrumen penelitian yakni semua alat yang digunakan untuk mengolah, menganalisis dan menyajikan data-data secara sistematis serta objektif, dengan tujuan untuk memecahkan suatu persoalan dalam penelitian yang disesuaikan dengan indikator-indikator dalam penelitian. Maka di dalam penelitian ini yang menjadi instrumen penelitiannya adalah. 
1) Teks ketujuh lirik lagu wajib nasional

2) Tabel korpus data, dengan bentuk tabel seperti berikut ini

\begin{tabular}{|l|l|l|}
\hline NO & $\begin{array}{l}\text { KATA/ } \\
\text { KALIMAT }\end{array}$ & $\begin{array}{l}\text { PENAFSIRAN } \\
\text { KATA/KALIMAT }\end{array}$ \\
\hline 1. & & \\
\hline 2. & & \\
\hline 3. & & \\
\hline \multicolumn{2}{|l|}{ TOTAL OF MEANING } \\
\hline
\end{tabular}

Keterangan Tabel

a) Kolom nomer, diisi sesuai nomer urut.

b) Kolom kata atau kalimat, diisi dengan kata atau kalimat yang diambil dari teks ketujuh lirik lagu wajib nasional.

c) Kolom penafsiran kata atau kalimat, diisi dengan penjelasan tentang makna atau kalimat yang ada pada kolom kata atau kalimat.

d) Kolom total of meaning, diisi dengan kesimpulan dari seluruh penafsiran pada tiap kata atau kalimat pada teks lirik lagu wajib nasional.

3) Konteks kultural

4) Biografi pengarang (konteks historis)

Dari keempat instrument tersebut kemudian diinterpretasikan guna menemukan hasil yang menjadi tujuan dalam penelitian ini.

\section{PEMBAHASAN}

Dalam pembahasan ini peneliti akan mendeskiripsikan hasil dari penelitian, deskripsi penelitian ini ditulis dengan tujuan agar pembaca mampu memahami dengan jelas hasil penelitian secara utuh. Penelitian ini dilakukan dengan menafsirkan dan menginterpretasikan pesan heroik yang terdapat di dalam tujuh lirik lagu wajib nasional yaitu,

1) lagu kebangsaan "Indonesia Raya" ciptaan Wage Rudolf Soepratman

2) lagu "Bagimu Negeri" ciptaan Kusbini

3) lagu "Maju Tak Gentar" ciptaan Cornel Simanjuntak

4) lagu "Halo-halo Bandung" ciptaan Ismail Marzuki

5) lagu "Rayuan Pulau Kelapa" ciptaan Ismail Marzuki

6) lagu "Berkibarlah Benderaku" ciptaan Ibu Soed (Saridjah Niung Bintang Soedibjo)

7) lagu "Satu Nusa Satu Bangsa" ciptaan Liberty Manik.

Dengan menggunakan perspektif hermeneutika, sebab naskah tulisan hasil cipta masa lampau, pada saat ini berada dalam kondisi yang tidak selalu dapat diterima dengan jelas dan sering dikatakan "gelap" atau "tidak jelas" oleh pembaca masa sekarang. Sebagai akibatnya, banyak karya tulisan masa lampau dirasakan tidak mudah dipahami (Baried, dkk 1994: 1). Jadi tugas hermeneutika adalah mencari dalam teks kemampuan karya untuk memproyeksikan diri keluar dari dirinya dan melahirkan suatu dunia yang merupakan pesan dari teks itu. Pesan yang dikaji dalam lirik lagu wajib nasional ini adalah pesan heroik yang dibagi menjadi dua unsur, yakni yang mengandung unsur nasionalisme dan patriotisme. Nasionalisme meliputi sifat 1) kebanggaan terhadap Negara, 2) cinta tanah air, 3) mengutamakan rasa persatuan dan kesatuan. Sedangkan patriotisme meliputi sifat, 1) rela berkorban, 2) berani berjuang, 3) pantang menyerah, 4) berjiwa pembaharu Serta menjelaskan fungsi pesan heroik tersebut dalam 
implementasinya pada pendidikan berkarakter di Indonesia.

\section{Definisi Sifat-Sifat Kepahlawanan}

Pendefinisian menurut Chaer (2009:53), yaitu usaha yang dilakukan dengan sengaja untuk mengungkapkan dengan kata-kata akan suatu benda, konsep, proses, aktivitas, peristiwa dan sebagainya. Jadi untuk memperjelas hasil dalam penelitian ini maka akan didefinisikan beberapa sifat yang menjadi pembahasan di dalam memahami pesan yang terdapat pada lirik lagu wajib nasional.

\section{a. Sifat-sifat Nasionalisme}

Nasionalisme yakni paham yang meletakkan kesetiaan tertinggi individu yang harus diberikan kepada negara dan bangsanya, dengan maksud bahwa individu sebagai warga negara memiliki suatu sifat, sikap atau perbuatan untuk mencurahkan segala tenaga dan pikirannya demi kemajuan, kehormatan dan tegaknya kedaulatan negara dan bangsa. Jadi sifat nasionalisme meliputi,

1) kebanggaan terhadap bangsa dan negara, yakni sifat besar hati terhadap suatu negara, karena memiliki keunggulan yang tidak dimiliki oleh negara yang lain

2) cinta tanah air, yakni sifat mengagumi, memuja serta menjunjung tinggi dan menganggap paling baik negara yang menjadi tempat hidupnya, sehingga akan menimbulkan sifat kesetiaan dan pengabdian yang tulus terhadap negara.

3) mengutamakan rasa persatuan dan kesatuan, yakni sifat lebih mementingkan persaudaraan, kebersamaan dan kerjasama dalam mencapai tujuan, serta saling memahami perbedaan dan kekurangan yang ada, sehingga memunculkan sifat saling menghargai.

\section{b. Sifat-sifat Patriotisme}

Patriotisme berdasarkan KBBI offline v.1.5 berasal dari kata "Patriot" yang diartikan pecinta atau pembela tanah air dan "isme" yakni sistim kepercayaan berdasarkan politik sosial dan ekonomi' Jadi patriotisme adalah sifat yang bersumber dari perasaan cinta tanah air (semangat kebangsaan atau nasionalisme), sehingga akan memunculkan sifat-sifat antara lain,

1) rela berkorban, adalah sifat tulus ikhlas bersedia memberikan pikiran, tenaga, harta, bahkan jiwa dan raganya untuk kepentingan bangsa dan Negara. Dan lebih mengutamakan kepentingan orang banyak dibandingkan kepentingan pribadi.

2) berani berjuang, yakni sifat berani dalam mempertahankan dan meraih sesuatu yang sudah menjadi hak atau tujuannya, sifat ini berhubungan erat dengan kebenaran, karena seseorang tidak akan merasa takut dan merasa gentar jika dia sedang memperjuangkan suatu kebenaran.

3) pantang menyerah, yakni sifat tidak mudah putus asa dalam berusaha, meskipun menghadapi berbagai rintangan dan kegagalan, tetap selalu mencoba sampai mendapatkan keberhasilan, hingga tujuan yang diinginkannya telah tercapai.

4) berjiwa pembaharu, yakni sifat untuk menemukan suatu hal yang baru dan belum pernah ada, yang membawa kemajuan serta kebaikan bagi dirinya, masyarakat, dan 
terutama bagi bangsa dan negaranya.

1. Wujud Pesan Kepahlawanan pada Syair Lagu Indonesia Raya

Dalam syair lagu Indonesia Raya terdapat berbagai pesan heroik, pesan-pesan tersebut antara lain terdapat pada lirik berikut ini,

\section{Nasionalisme}

1) Kebanggaan terhadap bangsa Indonesia yang terdapat pada kalimat,

Indonesia tanah airku, Tanah tumpah darahku,

Indonesia kebangsaanku, Bangsa dan Tanah Airku.

2) Rasa cinta terhadap Negara Indonesia, yang terdapat pada kalimat,

Tanahku negeriku yang kucinta

3) Pentingnya menanamkan rasa persatuan dan kesatuan, yakni pada lirik ,Marilah kita berseru, Indonesia bersatu

4) Selalu melakukan dan mempersembahkan yang terbaik bagi bangsa Indonesia, terdapat pada lirik, Bangunlah jiwanya, Bangunlah badannya, Untuk Indonesia Raya

\section{Patriotisme}

3) Sifat rela berkorban sebagai perwujudan dari sifat cinta tanah air, terdapat pada lirik ,

Disanalah aku berdiri, Jadi pandu ibuku Bangunlah jiwanya, Bangunlah badannya, Untuk Indonesia Raya

Implementasi Pesan Heroik Lirik Lagu Indonesia Raya dalam Pendidikan Berkarakter

Dalam pendidikan berkarakter, wujud pesan dalam lirik lagu Indonesia Raya ini sangat penting bagi anak didik untuk dapat menumbuhkan, rasa bangga, rasa cinta serta sikap rela berkorban untuk negara Indonesia, dan juga meningkatkan rasa persatuan dan kesatuan. Jadi bukan hanya menumbuhkan karakter sifat tetapi juga pada karakter sikap anak didik terhadap bangsa dan negaranya. Selain itu anak didik akan lebih memahami arti sebenarnya dari lagu kebangsaan Indonesia Raya.

2. Wujud Pesan Kepahlawanan pada Syair Lagu Bagimu Negeri

Syair lagu Bagimu Negeri memiliki beberapa pesan heroik yang terdapat pada beberapa lirik lagunya yakni,

\section{Nasionalisme}

1) Kesetiaan dan pengabdian terhadap bangsa dan Negara, terdapat pada kalimat, Padamu negeri kami berbakti, Padamu negeri kami mengabdi

\section{Patriotisme}

2) Rela berkorban demi bangsa dan Negara, terdapat pada lirik, bagimu negeri, jiwa raga kami

Implementasi Pesan Heroik Lirik Lagu Bagimu Negeri dalam Pendidikan Berkarakter

Pesan dalam lirik lagu Bagimu Negeri dalam hubungannya dengan pendidikan berkarakter dapat berperan untuk menanamkan sifat kesetiaan, pengabdian dan sikap rela berkorban untuk bangsa dan negara Indonesia di dalam diri anak didik. Sehingga anak didik dapat memahami dan mengerti tentang kesetiaan dan sikap rela berkorban yang ditujukan bagi bangsa dan negaranya, dan di masa mendatang mampu memberikan yang terbaik bagi bangsa dan negaranya.

3. Wujud Pesan Kepahlawanan pada Syair Lagu Berkibarlah Benderaku

Dalam lirik lagu Berkibarlah Benderaku ada beberapa pesan heroik 
yang terkandung didalamnya, pesan tersebut terdapat pada lirik yang dituliskan sebagai berikut,

\section{Nasionalisme}

1) Rasa Bangga terhadap bendera merah putih sebagai lambang negara Indonesia, yang terdapat pada kalimat Berkibarlah benderaku, Lambang suci gagah perwira

2) Sifat dan sikap menghormat bendera merah putih, terdapat pada kalimat Di seluruh pantai Indonesia, Kau tetap pujaan bangsa

\section{Patriotisme}

1) Sikap berani memperjuangkan dan menjaga kehormatan bendera merah putih, yang ada pada kalimat, Siapa berani menurunkan engkau, Serentak rakyatmu membela

2) Sifat dan sikap rela berkorban sampai kapanpun untuk menjaga kehormatan bendera merah putih, yang ada pada kalimat, Kami rakyat Indonesia, Bersedia setiap masa, Mencurahkan segenap tenaga, Supaya kau tetap cemerlang

Implementasi Pesan Kepahlawanan Syair Lagu Berkibarlah Benderaku dalam Pendidikan Berkarakter

Fungsi pesan yang terdapat pada lirik lagu Berkibarlah Benderaku dalam menanamkan pendidikan karakter terhadap anak didik yaitu, pesan heroik dalam lirik lagu ini dapat menumbuhkan sifat dan sikap menjunjung tinggi dan menghormati bendera merah putih, serta sikap berani berkorban dalam menjaga kehormatan bendera merah putih. Selain itu juga dapat membuat anak didik lebih mengenal dan memahami tentang arti sebenarnya dari sebuah bendera merah putih yang menjadi lambang kedaulatan negara Republik Indonesia.

4. Wujud Pesan Kepahlawanan pada Lirik Lagu Maju Tak Gentar

Dalam lirik lagu Maju Tak Gentar terdapat beberapa pesan heroik, yang pesan-pesan tersebut antara lain terdapat pada lirik seperti berikut ini,

\section{Nasionalisme}

Pentingnya rasa persatuan dan kesatuan dalam meraih kemenangan, yang terdapat pada kalimat, Maju serentak, Tentu kita kita menang

\section{Patriotisme}

Sifat dan sikap berani serta rela berkorban dalam mempertahankan hak yang dimilikinya, yang terdapat pada kalimat, Maju tak gentar, Hak kita diserang.

Implementasi Pesan Kepahlawanan Syair Lagu Maju Tak Gentar dalam Pendidikan Berkarakter

Dalam pendidikan berkarakter, pesan dalam lagu Maju Tak Gentar ini sangat penting peranannya dalam menumbuhkan karakter sifat dan sikap dalam diri anak didik untuk selalu menjaga persatuan dan kesatuan, serta berani dalam membela hal yang benar dan mempertahankan haknya. Jadi selain memiliki sikap dan sifat tersebut, anak didik juga akan memahami dan mengerti pentingnya persatuan dan kesatuan bagi negaranya, serta memahami bagaimana cara bersikap untuk menjaga hak yang dimiliki negara Indonesia yakni kemerdekaan.

5. Wujud Pesan Kepahlawanan pada Syair Lagu Satu Nusa Satu Bangsa

Ada beberapa pesan heroik yang terdapat pada lirik lagu Satu Nusa Satu Bangsa ini, pesan heroik tersebut terdapat pada lirik sebagai berikut, 
Nasionalisme

1) Pentingnya rasa persatuan dan kesatuan untuk menjaga keutuhan negara Indonesia, rasa kebersamaan dalam kerjasama, yang dituliskan pada kalimat,

Satu nusa, Satu bangsa, Satu bahasa kita

2) Rasa hormat dan cinta terhadap negara Indonesia, yang terdapat pada kalimat, Indonesia pusaka, Indonesia tercinta

\section{Patriotisme}

Sifat rela berkorban dalam menjaga negara Indonesia, yang terdapat pada kalimat, Nusa bangsa, dan bahasa, Kita bela bersama

Implementasi Pesan Heroik Lirik Lagu

Satu Nusa Satu Bangsa dalam Pendidikan Berkarakter

Dalam lirik lagu Satu Nusa Satu Bangsa ini terdapat tiga pesan yang mengandung unsur sifat nasionalisme dan satu sifat patriotisme, yang peranan wujud pesan dalam lagu tersebut sangat penting dalam menciptakan karakter anak didik supaya dapat bersikap menjaga persatuan dan kesatuan, serta memiliki sifat saling bekerjasama dalam kebaikan, saling menghormati, menghargai perbedaan serta mencintai negara Indonesia. Melalui pesan tersebut juga dapat memberikan pengertian dan pemahaman kepada anak didik tentang pentingnya sebuah persatuan dan kesatuan bagi keutuhan bangsa dan negara Indonesia.

6. Wujud Pesan Kepahlawanan pada Syair Lagu Halo-halo Bandung

Terdapat beberapa pesan heroik pada lirik lagu Halo-halo Bandung, pesan-pesan pada lirik lagu tersebut dapat dijelaskan sebagai berikut,

\section{Nasionalisme}

Rasa cinta terhadap kota yang menjadi bagian dari wilayah Indonesia, dan memunculkan rasa memiliki, yakni terdapat pada Lirik,

Halo-halo Bandung, lbukota periangan, Halo-halo Bandung, Kota kenang-kenangan

\section{Patriotisme}

Sifat berani dalam memperjuangkan dan mempertahankan bagian wilayah yang menjadi milik negara Indonesia, serta memiliki jiwa pembaharu dalam mengembalikan keadaan kota yang telah hancur, yang ada di dalam lirik,

Sekarang telah menjadi lautan api, Mari bung rebut kembali

Implementasi Pesan Kepahlawanan Syair lagu Halo-halo Bandung dalam Pendidikan Berkarakter

Lagu Halo-halo Bandung memiliki pesan heroik yang dapat diterapkan dalam pendidikan berkarakter untuk menumbuhkembangkan sifat dan sikap pada anak didik, karena dari pesan yang terdapat di dalam lirik lagu ini akan dapat menumbuhkan karakter anak didik yang mencintai, dan rasa memiliki setiap wilayah yang menjadi bagian dari negara Indonesia, serta menjaga dan memberikan yang terbaik bagi bangsa dan negara Indonesia. Jadi melalui pesan yang terdapat pada lirik lagu ini, anak didik akan mengerti pentingnya mencintai dan menjaga tiap bagian yang menjadi wilayah Indonesia, selain itu memberikan pemahaman kepada anak didik bahwa negara Indonesia merupakan negara yang besar dan memiliki berbagai kota yang indah yang harus dijaga dan dicintai oleh bangsanya yakni bangsa Indonesia. 
7. Wujud Pesan Kepahlawnan pada lirik lagu Rayuan Pulau Kelapa

Dalam lirik lagu Rayuan Pulau Kelapa terdapat pesan heroic di tiaptiap baitnya, yang dapat dijelaskan sebagai berikut ini,

\section{Nasionalisme}

1) Rasa memiliki dan cinta terhadap keindahan negara Indonesia, yang terdapat pada lirik,

Tanah airku Indonesia, Negeri elok amat kucinta

Memuja pulau, Nan indah permai, Tanah Airku, Indonesia

2) Rasa hormat, rasa bangga dan menjunjung tinggi negara Indonesia, yang terdapat pada lirik,

Tanah tumpah darahku yang mulia, Yang kupuja sepanjang masa

Pulau melati pujaan bangsa, Sejak dulu kala

Implementasi Pesan Kepahlawanan Syair Lagu Rayuan Pulau Kelapa dalam Pendidikan Berkarakter

Dalam lirik lagu Rayuan Pulau Kelapa ini hanya terdapat pesan nasionalisme saja, tetapi pesan yang terdapat pada lirik lagu ini sangat penting peranannya dalam menumbuhkembangkan karakter anak didik baik sifat maupun tingkah laku. Yakni supaya selalu mencintai, mengagumi dan menjaga keindahan serta kekayaan alam di Indonesia, juga menumbuhkan sifat bangga terhadap bangsa dan negaranya karena berbagai keunggulan yang dimiliki. Jadi anak didik juga akan lebih memahami dan mengerti tentang segala keunggulan dan kebaikan khususnya kekayaan alam yang terdapat pada negara Indonesia.

8. Fungsi Pesan Heroik pada Lirik Lagu Wajib Nasional terhadap

\section{Pendidikan Berkarakter di Indonesia}

Berdasarkan dari implementasi pesan heroik yang terdapat pada tiap lirik lagu wajib nasional terhadap pendidikan berkarakter di Indonesia, maka dari ketujuh lirik lagu wajib nasional yaitu, 1) Lagu kebangsaan "Indonesia Raya" ciptaan Wage Rudolf Soepratman, 2) Lagu "Bagimu Negeri" ciptaan Kusbini, 3) Lagu "Maju Tak Gentar" ciptaan Cornel Simanjuntak, 4) Lagu "Halo-halo Bandung" ciptaan Ismail Marzuki, 5) Lagu "Rayuan Pulau Kelapa" ciptaan Ismail Marzuki, 6) Lagu "Berkibarlah Benderaku" ciptaan Ibu Soed (Saridjah Niung Bintang Soedibjo), 7) Lagu "Satu Nusa Satu Bangsa" ciptaan Liberty Manik, masing-masing dari tiap lirik lagu tersebut memiliki pesan heroik tersendiri, semua pesan yang terdapat pada ketujuh lirik lagu wajib nasional itu memiliki fungsi penting dalam menunjang pendidikan berkarakter di Indonesia.

Hal ini karena wujud pesan yang terdapat pada lirik lagu wajib nasional sangat sesuai dengan karakter bangsa yang harus dikembangkan dalam diri tiap anak didik. Pesan-pesan heroik tersebut yakni, nasionalisme yang terdiri dari sifat,

1) rasa bangga kepada bangsa dan Negara,

2) cinta tanah air, dan

3) menjaga persatuan dan kesatuan.

Serta patriotisme terdiri dari sifat,

1) rela berkorban,

2) berani berjuang,

3) pantang menyerah, dan

4) bersifat pembaharu.

Dari ke-18 unsur nilai karakter yang ditetapkan oleh Pemerintah Indonesia, semua pesan heroik 
tersebut sesuai dengan karakter bangsa pada unsur nilai cinta tanah air, yaitu cara berfikir, bersikap, dan berbuat yang menunjukkan kesetiaan, kepedulian, dan penghargaan yang tinggi terhadap bahasa, lingkungan fisik, sosial, budaya, ekonomi, dan politik bangsa. Jadi fungsi dari pesan heroik yang terdapat pada lirik lagu wajib nasional ini dapat diimplementasikan dalam pendidikan karakter bangsa guna menciptakan generasi penerus yang dapat memajukan bangsa dan negara Indonesia.

\section{KESIMPULAN}

Berdasarkan penafsiran dan interpretasi yang dilakukan peneliti dengan menggunakan perspektif hermeneutik terhadap tujuh buah lagu wajib nasional yakni, 1) lagu kebangsaan "Indonesia Raya" ciptaan Wage Rudolf Soepratman, 2) lagu "Bagimu Negeri" ciptaan Kusbini. 3) lagu "Maju Tak Gentar" ciptaan Cornel Simanjuntak, 4) lagu "Halo-halo Bandung" ciptaan Ismail Marzuki, 5) lagu "Rayuan Pulau Kelapa" ciptaan Ismail Marzuki, 6) lagu "Berkibarlah Benderaku" ciptaan Ibu Soed (Saridjah Niung Bintang Soedibjo), 7) lagu "Satu Nusa Satu Bangsa" ciptaan Liberty Manik, maka dapat diambil kesimpulan sebagai berikut.

1) Dalam ketujuh lirik lagu wajib nasional tersebut terdapat bebagai macam pesan heroik yang diartikan sebagai sifat kepahlawanan antara lain, nasionalisme dan patriotisme. Nasionalisme meliputi sifat, 1) kebanggaan terhadap negara, 2) cinta tanah air, 3) mengutamakan rasa persatuan dan kesatuan. Sedangkan Patriotisme meliputi, 1) sifat rela berkorban, 2) berani berjuang, 3) pantang menyerah, 4) berjiwa pembaharu.

2) Ada 18 unsur nilai karakter di dalam pendidikan berkarakter di Indonesia. Jika diimplementasikan dalam pendidikan berkarakter, fungsi dari wujud pesan heroik di dalam lagu wajib nasional sangat penting sekali guna mengembangkan karakter anak didik di sekolah. Khususnya karakter pada unsur nilai cinta tanah air, yakni cara berfikir, bersikap, dan berbuat yang menunjukkan kesetiaan, kepedulian, dan penghargaan yang tinggi terhadap bahasa, lingkungan fisik, sosial, budaya, ekonomi, dan politik bangsa.

3) Lagu perjuangan Indonesia diciptakan oleh para komponiskomponis dengan tujuan untuk meningkatkan semangat juang masyarakat Indonesia dalam merebut dan memertahankan kemerdekaan. Para komponis pencipta ketujuh lagu wajib nasional ini adalah merupakan para musisi bangsa yang berjasa besar dalam sejarah kemerdekaan Negara Indonesia, dan telah mendapatkan gelar pahlawan serta penghargaan dari Pemerintah Republik Indonesia.

4) Secara umum hermeneutika adalah sebuah cabang ilmu yang menjelaskan suatu teks, wacana, syair, dan lain-lain dengan cara menafsirkan dan menginterpretasikan susunan kata, kalimat dan juga sejarahnya. Oleh sebab itu dalam menafsirkan dan menginterpretasikan ketujuh lirik lagu wajib nasional tersebut, kajian hermeneutika sangat diperlukan 
sebagai landasan teori untuk memahami pesan yang terkandung di dalam lirik lagu tersebut.

\section{SARAN}

Guna peningkatan karakter anak dalam dunia pendidikan dan pengenalan lagu perjuangan bagi masyarakat Indonesia, maka saran ditujukan kepada beberapa pihak antara lain.

\section{1) Sekolah}

Bagi sekolah ada baiknya mewajibkan anak didik untuk menghafalkan beberapa lagu wajib nasional, karena langkah ini selain mengenalkan siswa pada lagu perjuangan yang menjadi bagian dari sejarah perjuangan bangsa, juga upaya untuk melestarikan lagu wajib nasional agar tidak hilang dan tergantikan oleh lagu-lagu pada masa sekarang.

2) Guru

Bagi guru ada baiknya dalam mengajarkan lagu wajib nasional bukan hanya lirik dan cara menyanyikannya saja yang diajarkan, tetapi juga dijelaskan tentang sejarah yang melatarbelakangi diciptakannya lagu tersebut agar anak didik lebih mengenal sejarah, biografi pengarangnya agar anak didik lebih mengenal sosok penciptanya serta bisa menjadi suri tauladan bagi mereka, dan yang terakhir makna dan pesan yang terkandung dalam lirik lagu wajib nasional, karena hal tersebut akan dapat memunculkan dan mengembangkan karakter anak didik tentang sifat-sifat heroik yakni nasionalisme dan patriotisme.

\section{3) Siswa}

Bagi siswa diharapkan dapat mengenal dan memahami lagu wajib nasional dari berbagai aspek, yakni mengetahui lirik lagu dan cara menyanyikannya yang baik dan benar, sejarah diciptakannya lagu wajib nasional, makna dan pesan yang terkandung di dalam lirik lagu tersebut, dan latar belakang pengarangnya.

\section{4) Pembaca}

Bagi pembaca akan dapat lebih mengenal dan memahami tentang lagu wajib nasional dari berbagai aspek, sehingga diharapkan pembaca dapat menghormati dan menghargai lagulagu wajib nasional, dan yang lebih penting lagi bersedia melestarikan lagu wajib nasional tersebut, agar lagu wajib nasional tidak hanya dikenang tetapi juga dikenal dan dipahami lebih komprehensif oleh bangsanya sendiri sampai kapanpun. Serta lagu wajib nasional bisa menjadi bagian dari budaya musik dan lagu di Indonesia.

\section{5) Bagi Peneliti Selanjutnya}

Hasil dari penelitian ini diharapkan dapat dijadikan sebagai bahan acuan untuk penelitian selanjutnya, terutama yang berhubungan dengan lirik lagu perjuangan Indonesia dan hermeneutika.

Abdurrahman, Dudung. 1999. Metode Penelitian Sejarah. Jakarta: Logos Wacana Ilmu.

Badudu, JS,. 2003. Kamus Kata-kata Serapan Asing dalam Bahasa Indonesia. Jakarta: PT Kompas Media Nusantara.

Bagus, Lorens. 2000. Kamus Filsafat. Jakarta: PT Gramedia Pustaka Utama.

Bakker, Anton. 1984. Metode-metode Filsafat. Jakarta: Ghalia Indonesia..

Byru, Langit. 2009. Pahlawan Nasional: Komponis Inonesia. http://www.indonesiaindonesia.com/ f/4393/(16 Desember 2011). 
Chaer, Abdul,. 2009.Pengantar Semantik Bahasa Indonesia. Yogyakarta: Pustaka Pelajar.

Ensiklopedia Musik. 1992. Jakarta: PT Cipta Adi Pustaka.

Hurek, Lambertus. 2007. Sedikit Tentang Lagu wajib Nasional. http://hurek.blogspot.com/2007/08/s edikittentang lagu perjuangan wajib nasional.html(16 Desember 2011).

Kamus Besar Bahasa Indonesia (KBBI) Offline. 2011

Makki, Ahmad. 2008. Menyoal Syair dan Tema-tema Lagu perjuangan Indonesia.

http://kacajendela.wordpress.com/20 08/11/13/menyoal-syair-dan-temalagu-lagu-indonesia/(16 Desember 2011).

Mintargo, Wisnu. 2008. Musik Revolusi Indonesia. Yogyakarta: Ombak.

Moleong, Lexy J,. 2009. Metodologi Penelitian Kualitatif. Bandung: PT. Remaja Rosdakarya.

Nation Master. Com, Biografi W.R Soepratmanhttp://www.statemaster. com/encyclopedia/Wage-RudolfSupratman(16 Desember 2011).

Nation Master. Com, Biografi Komponis Indonesia. http://www.statemaster.com/encyclo pedia/Biografi Komponis Indonesia (16 Desember 2011).

Nazir, M. 1988. Metodologi Penelitian. Jakarta: Galia Indonesia.

Palmer, Richard E,. 2005. HermeneutikaTeori Baru Mengenai Interpretasi. Yogyakarta: Pustaka Pelajar.

Pasaribu, Amir. 1986. Analisis Musik Indonesia. Jakarta: PT. Pantja Simpati.
Poespoprodjo, W. 2004. Hermeneutika. Bandung: CV. Pustaka Setia.

Raharjo, Mudjia. 2008. Dasar-dasar Hermeneutika: Antara Intensionalisme dan Gadamerian. Yogyakarta: Ar-Ruzz Media.

Rosyidi, M Ikhwan. 2008.Analisis Teks Sastra.Yogyakarta: Graha Ilmu.

Sudarto. 1997. Metodoliogi Penelitian Filsafat. Jakarta: PT. Raja Grafindo Persada.

Sugiyono. 2008. Metode Penelitian Kuantitatif Kualitatif dan $R \& D$. Bandung: CV. Alfabeta.

Sularto, Bambang. 2007. Sejarah Lagu Kebangsaan Indonesia Raya. Jakarta: Balai Pustaka.

Sumaryono, E. 1999. Hermeneutik, Sebuah Metode Filsafat. Yogyakarta: Kanisius.

Suprayogo, Imam dan Tobroni. 2001. Metodologi Penelitian SosialAgama. Bandung: PT Remaja Rosdakarya.

Wisnumintargo.Peranan Lagu dalam Sejarah Kemerdekaan.http://wisnumintargo web.ugm.ac.id(3 pebruari 2012). 